\title{
The strategy of simulation effects of wind speed, variation of turbine blades and it's interaction to power generated by vertical axis wind turbine using NACA 2412
}

\author{
Bambang Sugiyono Agus Purwono ${ }^{1 *}$, Masroni ${ }^{2}$, Awan Setiawan ${ }^{2}$, Tundung Subali Patma ${ }^{2}$, Ida Bagus Suardika ${ }^{2}$ \\ ${ }^{1}$ Mechanical Engineering Department, State Polytechnics of Malang \\ ${ }^{2}$ Industrial Engineering Department, Institut Teknologi Nasional - Malang Jl. Soekarno - Hatta No. 9, Malang 65141, Indonesia \\ *Corresponding author E-mail: bambangsap2010@gmail.com
}

\begin{abstract}
The objective of this paper is to simulate the effects upon the wind speed, variation of turbine blades and interaction of wind speed and variation of turbine blades to the power capacity generated by Vertical Axis Wind Turbine (VAWT) using NACA 2412 and to stratify the power capacity generated by the VAWT simulation. The research backgrounds are the wind-energy potential in Indonesia is about 9.290 MW and has already elaborated by Ministry of Mining, and Energy Resources is about 50 MW. This wind energy is environmentally (clean energy), economically (cheapest), easy to operate and easy to maintain, also renewable energy. The method of analysis is quantitative approach using two way classification (analysis of variance or design of experiments). The research variables are wind speed, variation of turbine blades and this interaction among independent variables and the power capacity as dependent variables. Data wind speed simulation vary from $3 \mathrm{~m} / \mathrm{s}$ till $6 \mathrm{~m} / \mathrm{s}$. The quantity of turbine blades vary from 3 till 8 units. The finding from this research is accepted the null hypothesis or not differ significantly at $5 \%$ from each independent variable. The scenario and the parameters during the strategy development use turbine blades, wind speed and power generated by VAWT and the maximum power generated is 16.38 watt. The wind speed is $6 \mathrm{~m} / \mathrm{s}$ and the number of turbine blade is 4 units. However, the minimum power generated by VAWT is 0.45 watt, the wind speed is $6 \mathrm{~m} / \mathrm{s}$ and the number of turbine blade is 3 units.
\end{abstract}

Keywords: VAWT; NACA 2412; Wind Speed; Turbine Blades; Power; Renewable Energy.

\section{Introduction}

The Indonesian energy consumption is increasing very rapidly, especially consumption energy for industries, transportation, commercial buildings and household sector (see Table 1), because of population growth, and economic growth energy.

Table 1: Share of Final Energy Consumption by Sector [\%]

\begin{tabular}{llllll}
\hline Year & Industry & Household & Commercial & Transportation & Other \\
\hline 2010 & 41.09 & 13.14 & 4.79 & 36.56 & 4.42 \\
2011 & 42.91 & 11.50 & 4.47 & 36.01 & 4.05 \\
2012 & 42.85 & 11.58 & 4.59 & 37.61 & 3.36 \\
2013 & 42.12 & 11.56 & 4.25 & 38.80 & 3.26 \\
\hline
\end{tabular}

Source: http://www.esdm.go.id/. Accessed on July 16, 2015[6].

The fuel or energy consumption increases rapidly but decreases the fuel production (see Fig. 1), so the gap between the fuel or energy consumption and fuel production is wider, it means the government should import the fuel from other countries more than 150.000 bpd in 2014 and increasing the fuel subsidy (http://www.kompas.com/. Accessed on July 4, 2015)[7]. The decreasing of the deposit/stock of the fossil fuel, the increasing price of the crude oil, the increasing need for the crude oil, the need for the alternative energy or renewable energy (see Fig. 1).

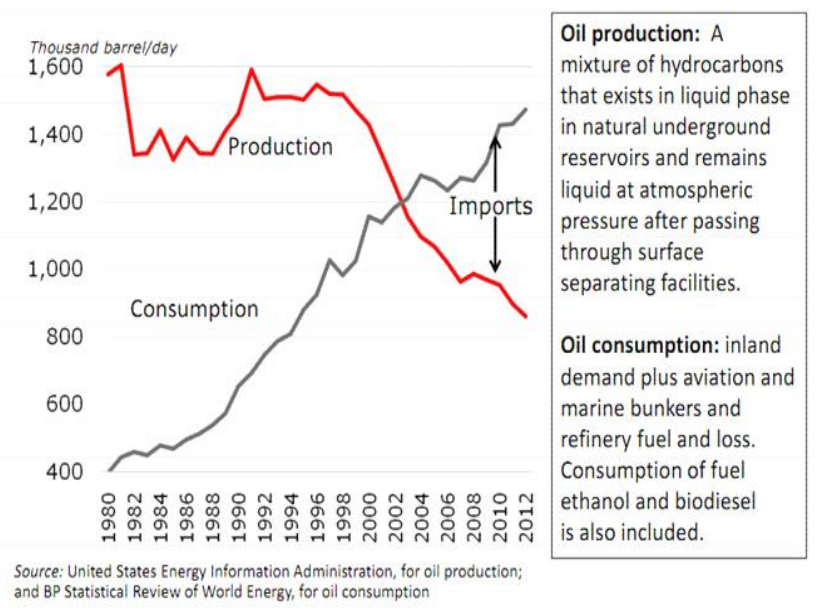

Fig. 1: Oil Production and Oil Consumption [5].

Many countries tried to generate or shift an alternative energy from nonrenewable energy to renewable energy. Renewable energy is energy generated from natural resources - such as sunlight, wind, rain, tides and geothermal - which are renewable (naturally replenished). One of the alternative energy and clean energy is wind energy. Concerning with the pollution, the content of the exhaust gas or the emission of the exhaust gas from the public transportation and private cars, commercial buildings, industries, and the households sectors tend to increase (see Table 1). Table 2 
shows us the potential energy and energy stock that have not been explored efficiently and effectively.

Table 2: Stock and Energy Production in Indonesia Year 2007 (Non fossil Energy)

\begin{tabular}{|c|c|c|c|}
\hline No. & $\begin{array}{l}\text { Non fossil } \\
\text { Energy }\end{array}$ & Energy Potential & $\begin{array}{l}\text { Available } \\
\text { capacity }\end{array}$ \\
\hline 1. & Hydro power & $\begin{array}{l}75,67 \text { GW (e.q. } 845 \text { juta } \\
\text { SBM) }\end{array}$ & $4,2 \mathrm{GW}$ \\
\hline 2. & Geothermal & $\begin{array}{l}27 \mathrm{GW} \text { (e.q. } 219 \text { juta } \\
\text { SBM) }\end{array}$ & $0,8 \mathrm{GW}$ \\
\hline 3. & $\begin{array}{l}\text { Mini/micro } \\
\text { hydro }\end{array}$ & $0,45 \mathrm{GW}$ & $0,084 \mathrm{GW}$ \\
\hline 4. & Bio-mass & $49,81 \mathrm{GW}$ & $0,3 \mathrm{GW}$ \\
\hline 5. & Solar energy & $4,8 \mathrm{kWh} / \mathrm{m} 2 / \mathrm{day}$ & $0,008 \mathrm{GW}$ \\
\hline 6. & Wind energy & $9,29 \mathrm{GW}$ & $0,0005 \mathrm{GW}$ \\
\hline 7. & Uranium *) & $3 \mathrm{GW}$ (e.q. 24,112 ton) & $30 \mathrm{GW}$ \\
\hline
\end{tabular}

The stock and production of wind energy is more than 9,290 MW, what has been done and what has already been produced is about $50 \mathrm{MW}$. At present the government of the Republic of Indonesia is still installing the horizontal axis wind turbines (HAWT) that produces about $50 \mathrm{MW}$ (30 units) in Yogyakarta - the Samas beach Centre Java. It means the government has already started to promote the green technology (http://www.kompas.com/. Accessed on July 4, 2015, and http://www.ebtke.esdm.go.id/. Accessed on July 16, 2015)[7][8].

Table 3: The Development of Fuel Subsidy (2011-2013) [Rp. $10^{12}$

\begin{tabular}{lllll}
\hline No. & Type of subsidy & 2011 & 2012 & 2013 \\
\hline 1 & Fuel, LPG, Alternative energy & 165.16 & 211.90 & 193.80 \\
2 & Public electricity & 90.45 & 94,58 & 80,94 \\
Total & & 245.61 & 306.48 & 274.74 \\
\hline
\end{tabular}

Source: http://www.kompas.com/. Accessed on July 4, 2015 and Partowidagdo, W, 2010:532[7][17].

The objectives of this research is to analyze the effects of the wind speed, the number of turbine blades and interaction of the wind speed and the number of turbine blades to the power generated by Vertical Axis Wind Turbines (VAWT) using NACA 2412 (Seetharam, HC, and EJ Rodgers and WH Wentz, Jr. 1977, and Veers, PS. 1983)[16][17] and to stratify the power generated by the VAWT simulation.

Table 3 shows us the increasing of the government financial support for fuel subsidiary every year.

\section{Theoretical background}

This section discusses the airfoil, NACA 2412, and turbine blade. Airfoil is a structure with curved surfaces designed to give the most favorable ratio of lift to drag in flight, used as the basic form of the wings, fins, and horizontal stabilizer of most aircraft also airfoil (Figures 2, 3 and 4).

\subsection{Turbine blades}

Airfoil shape has an influence on the flow characteristics that passing through because of the radius of the leading edge of the airfoil, maximum chamber and maximum thickness position of the airfoil. The maximum thickness position of the airfoil will also affect the other variables, such as the location of the point of minimum pressure and generated pressure distribution.

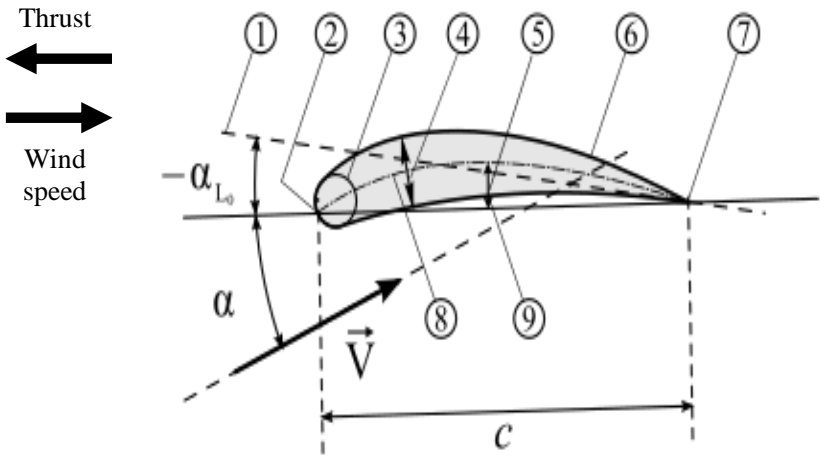

Fig. 2: Profile Geometry Airfoil [2], [12]

1: Zero lift line; 2: Leading edge; 3: Nose circle; 4: Camber; 5: Max thickness; 6: Upper surface; 7: Trailing edge; 8: Camber mean-line; 9: Lower surface

The position of the minimum pressure point should be as far back towards the trailing edge to ensure the transition from laminar flow to turbulent emergence as slowly as possible so as to reduce friction drag on the profile (Figures 2, 3 and 4). An airfoil-shaped body moved through a fluid produces an aerodynamic force. The component of this force perpendicular to the direction of motion is called lift. The component parallel to the direction of motion is called drag (Figure 3).

(A)

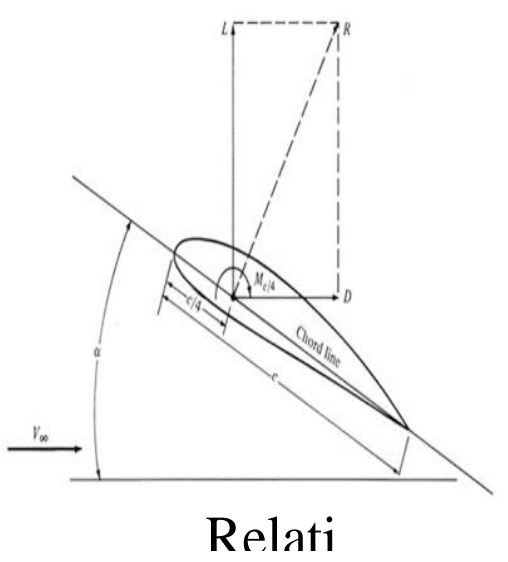

(B)

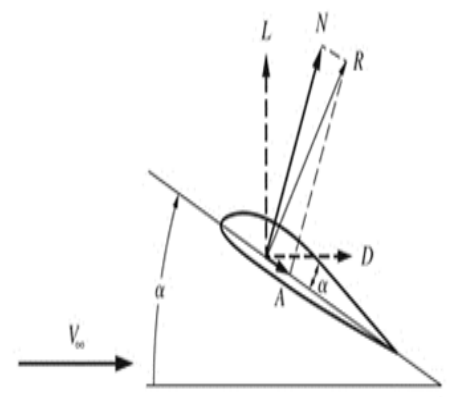

Fig. 3: Lift, Drag and Resultant Force (A) Lift and Drag, Moments, Angle of Attack and Relatif Wind; (B) Normal and Axial Force.

Source: http://www.en.wikipedia.org/wiki/simulation. Accessed on July $16,2015 .[11]$.

\subsection{Simulation}

Simulation is the imitation of the operations of various kinds of real-world facilities or processes or system. The act of simulating 
something first requires that a model be developed; Model represents the form of mathematical or logical relationships; this model represents the key characteristics or behaviors/functions of the selected physical or abstract system or process. The model represents the system itself, whereas the simulation represents the operation within the system (see Figure 5). Simulation is used in many contexts, such as simulation of technology for performance optimization, safety engineering, testing, training, education, and video games. Often, computer experiments are used to study simulation models. Simulation is also used with scientific modeling of natural systems or human systems to gain insight into their functioning. Simulation can be used to show the eventual real effects of alternative conditions and courses of action (http://www.en.wikipedia.org/ wiki/simulation. Accessed on July 16, 2015 and Laws AM and W David Kelton. 1982) [11].

\subsection{Strategy}

The terminology of strategy is strategos (Greek) which is the combination from two words "stratos" means "army" and "ago" means "leading/guiding/moving to". So the strategy means the art of the military operation planning and management in big scale and to direct to benefit position before the real battle with the enemy occurred. Wheelen (Wheelen, T L., and Hunger, JD. 2004) stated that "A strategy of a corporate forms a comprehensive master plan stating how the corporation will achieve its mission and objectives."[19].

\subsection{Scenario}

Scenario is an imagined or projected sequence of events, especially any of several detailed plans or possibilities: One scenario calls for doubling profits by increasing our advertising, the other by reducing costs.

\section{Proposed method}

The research variables are the wind speed, the number of the turbine blades, and the interaction of the wind speed and the number of the turbine blades as independent variables, and the power generated by Vertical Axis Wind Turbines (VAWT) using NACA 2412 as a dependent variable. The mathematical model (Hicks, CR. 1982) [5] is.

$\mathrm{Y}_{\mathrm{ijk}}=\mu+\mathrm{WS}_{\mathrm{i}}+\mathrm{TB}_{\mathrm{j}}+\mathrm{WSTB}_{\mathrm{ij}}+\varepsilon_{\mathrm{k}(\mathrm{ij})}$.

This research applies quantitative approach using factorial experiments. The data of wind speed vary from $3.5 \mathrm{~m} / \mathrm{s}$ to $6 \mathrm{~m} / \mathrm{s}$. The number of the turbine blades vary from using 3, 4, and 6 units of turbine blades. Tests of hypotheses: the null hypotheses are accepted if the means from the variables data are not different significantly at the level 5\%, and the null hypotheses are rejected if the means of the variables are different significantly at the level $5 \%$. The accumulation of data wind speed can be measured by using the digital anemometer, whereas the power is a multi-testers $(\mathrm{W}=\mathrm{V} \times \mathrm{A}$ or volt times ampere).

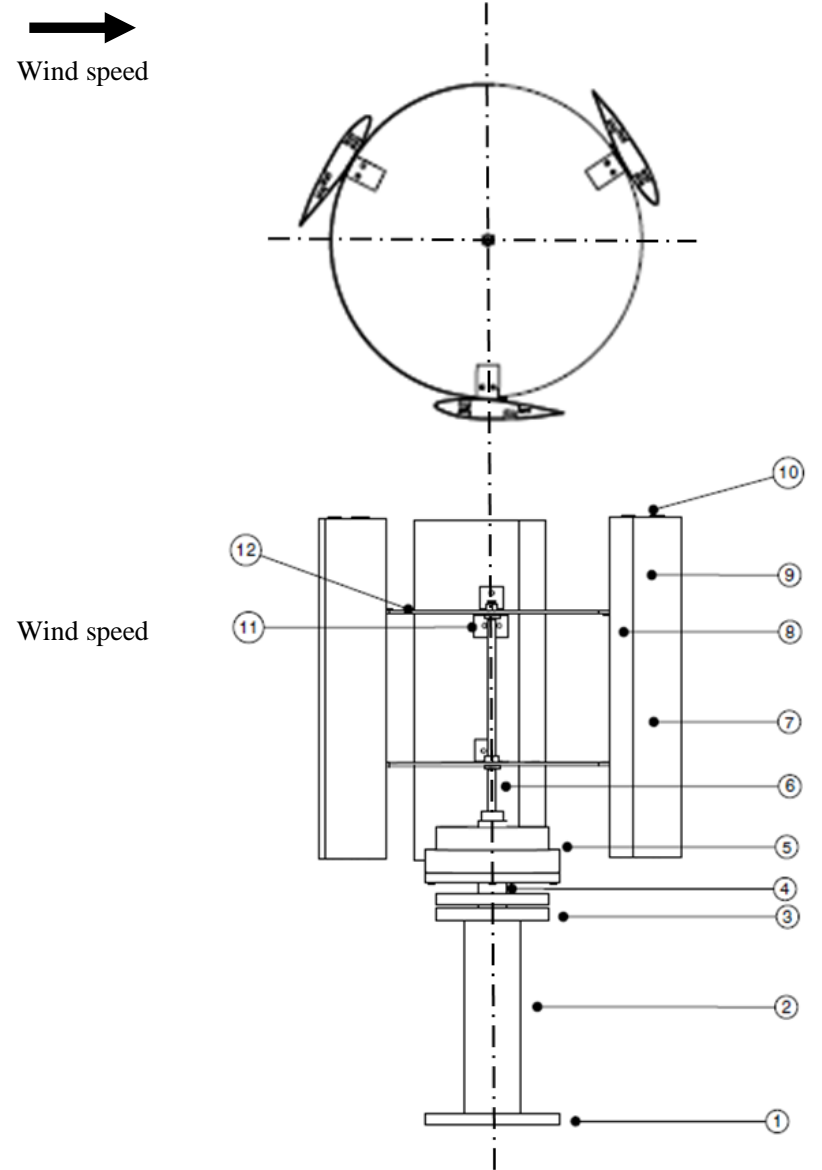

Fig. 4: Turbine Blades VAWT 1. Flange; 2. Shaft; 3. Flange; 4. Pipe; 5. Magnet Generator; 6. Shaft; 7. Blades; 8. Blades' Frame; 9. Shield; 10. Airfoil Aluminium Sheet; 11. Bracket; 12. Al Sheet Blades' Disk).

\subsection{Development strategy}

Table 6 shows the scenario and the parameters of the strategy development uses turbine blades, wind speed and power generated by VAWT. The maximum power generated by VAWT is 16.38 watt, the wind speed is $6 \mathrm{~m} / \mathrm{s}$ and the number of turbine blade is 4 unit and the minimum power generated by VAWT is 0.45 watt, the wind speed is $6 \mathrm{~m} / \mathrm{s}$ and the number of turbine blade is 3 unit (see Table 6 and Figure 4).

\section{Result and discussion}

The $\mathrm{F}$ ratio is bigger than $\mathrm{F}$ table (see Table 5) or $4.53>2.61$, it means the null hypothesis is rejected or the average wind speed to the power generated by VAWT is different significantly at $5 \%$. The $\mathrm{F}$ ratio is bigger than $\mathrm{F}$ table (see Table 5) or $16.52>2.84$, it means the null hypothesis is rejected or the average number of turbine blade to the power generated by VAWT is different significantly at $5 \%$. The $\mathrm{F}$ ratio is bigger than $\mathrm{F}$ table (see Table 5) or $152.39>2.00$, it means the null hypothesis is rejected or the average of interaction between wind speed and the number of turbine blade to the power generated by VAWT is different significantly at $5 \%$. Table 7 shows us the scenario and the parameters of the strategy development which uses turbine blades, wind speed and power generated by VAWT and the maximum power generated by VAWT is 16.38 watt, the wind speed is $6 \mathrm{~m} / \mathrm{s}$ and the number of turbine blade is 4 unit and the minimum power generated by VAWT is 0.45 watt, the wind speed is $6 \mathrm{~m} / \mathrm{s}$ and the number of turbine blade is 3 unit (see Table 6 and Figure 6). 


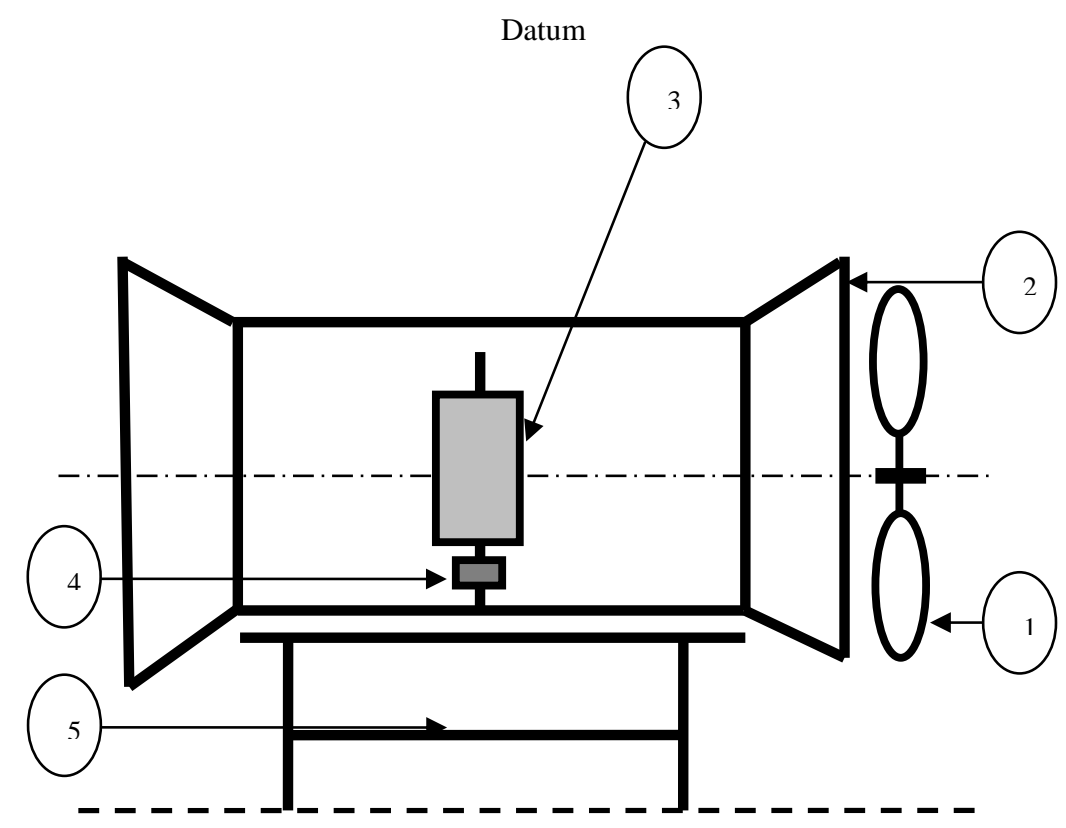

Fig. 5: Wind Tunnel (1. Blower; 2. Wind Tunnel; 3. Turbine Blades; 4. Generator; 5. Table).

Table 4: Wind Speed [M/S], Turbine Blades [Unit], and Power [Watt]

\begin{tabular}{|c|c|c|c|c|c|}
\hline \multirow{3}{*}{ Turbines Blades } & \multicolumn{5}{|c|}{ Wind Speed [m/s] } \\
\cline { 2 - 6 } & 3.5 & 4 & 5 & 5.5 & 6 \\
\hline \multirow{3}{*}{3 blades } & 1.68 & 0.8 & 0.68 & 0.54 & 0.37 \\
\cline { 2 - 6 } & 0.92 & 1.6 & 0.6 & 0.96 & 0.58 \\
\cline { 2 - 6 } & 1.6 & 1.52 & 0.6 & 0.91 & 0.55 \\
\cline { 2 - 6 } & 1.76 & 0.72 & 0.64 & 0.46 & 0.29 \\
\hline \multirow{3}{*}{4 blades } & 7 & 6.4 & 8.04 & 17.6 & 16.4 \\
\cline { 2 - 6 } & 7 & 7.68 & 12.4 & 13 & 14.4 \\
\cline { 2 - 6 } & 7 & 7.44 & 13.4 & 11.34 & 17.5 \\
\cline { 2 - 6 } & 7 & 7.92 & 8.4 & 11.75 & 17.2 \\
\hline \multirow{3}{*}{6 blades } & 1.62 & 1.44 & 1.8 & 4.8 & 6.96 \\
\cline { 2 - 6 } & 2 & 1.38 & 1.86 & 6 & 6.96 \\
\cline { 2 - 6 } & 1.84 & 1.5 & 1.8 & 5.4 & 5.2 \\
\hline
\end{tabular}

Source: Research data processed (Hicks, CR.1982)[5].

Table 5: Anova Results

\begin{tabular}{|l|c|r|r|r|r|}
\hline \multicolumn{1}{|c|}{ Source } & df & \multicolumn{1}{c|}{ SS } & \multicolumn{1}{c|}{ MS } & \multicolumn{1}{c|}{ F ratio } & F table \\
\hline Between Factor WS & 4 & 183.33 & 45.83 & 31.23 & 2.61 \\
\hline Between Factor TB & 3 & $1,097.67$ & 365.89 & 249.31 & 2.84 \\
\hline WS by TB interaction & 12 & 160.73 & 13.39 & 9.13 & 2.00 \\
\hline Error & 40 & 58.70 & 1.47 & & \\
\hline Totals & 59 & $1,500.44$ & & & \\
\hline
\end{tabular}

Source: Research data processed (Hicks, CR.1982)[5].

Table 6: The Average of Wind Speed [M/S], Turbine Blades [Unit], and the Average of Power [Watt]

\begin{tabular}{|l|r|r|r|r|r|}
\hline \multirow{2}{*}{ Turbine Blades } & \multicolumn{5}{|c|}{ Average Wind speed [m/s] } \\
\cline { 2 - 6 } & 3.5 & 4 & 5 & 5.5 & 6 \\
\hline 3 blades & 1.49 & 1.16 & 0.63 & 0.72 & 0.45 \\
\hline 4 blades & 7.00 & 7.36 & 10.56 & 13.42 & 16.38 \\
\hline 6 blades & 1.87 & 1.44 & 1.83 & 5.35 & 6.34 \\
\hline
\end{tabular}


Power [watt]

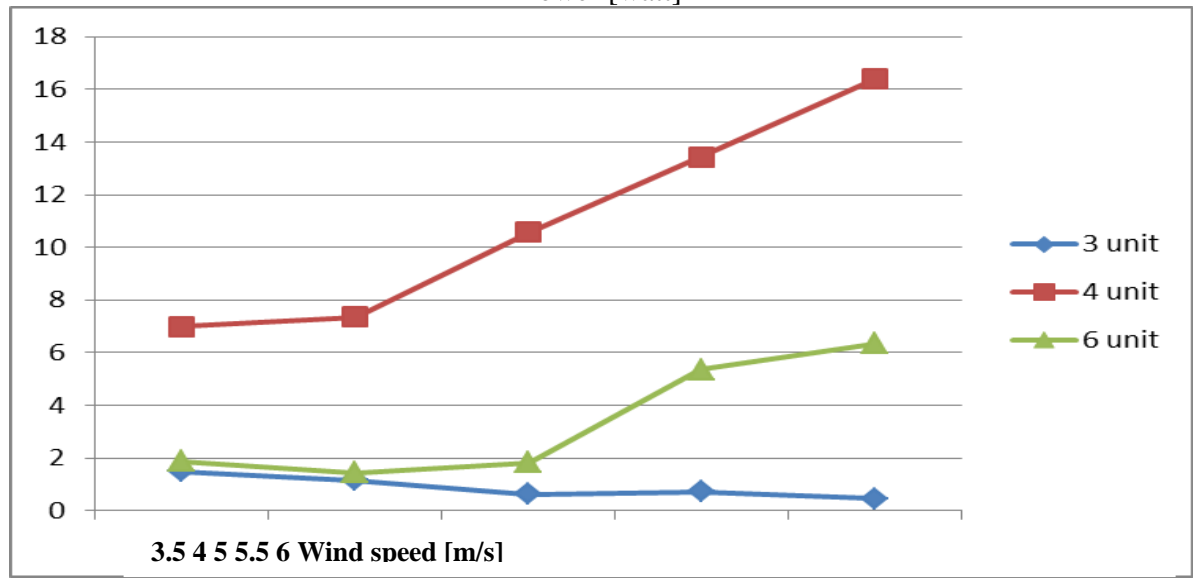

Fig. 6: Wind Speed, Power and Number of Turbine Blades.

Source: Research data processed (Hicks, CR.1982)[5].

Table 7: The Strategy Development [3]

\begin{tabular}{|c|c|c|c|}
\hline No & Strategy & Alternative & Remark \\
\hline 1 & Scenario 1 & $\begin{array}{l}\text { The maximum power generated by VAWT uses } 4 \text { unit of turbine blades, the } \\
\text { wind speed is } 6 \mathrm{~m} / \mathrm{s} \text {, and the power generated by VAWT is } 16.38 \text { watt. }\end{array}$ & $\begin{array}{l}\text { The base line is } 4 \text { unit of turbine } \\
\text { blades. }\end{array}$ \\
\hline 2 & Scenario 2 & $\begin{array}{l}\text { The minimum power generated by VAWT uses } 4 \text { unit of turbine blades, the } \\
\text { wind speed is } 5.5 \mathrm{~m} / \mathrm{s} \text {, and the power generated by VAWT is } 7 \text { watt. }\end{array}$ & $\begin{array}{l}\text { The base line is } 4 \text { unit of turbine } \\
\text { blades. }\end{array}$ \\
\hline 3 & Scenario 3 & $\begin{array}{l}\text { The maximum power generated by VAWT uses } 6 \text { unit of turbine blades, the } \\
\text { wind speed is } 6 \mathrm{~m} / \mathrm{s} \text {, and the power generated by VAWT is } 6.34 \text { watt. }\end{array}$ & $\begin{array}{l}\text { The base line is } 6 \text { unit of turbine } \\
\text { blades. }\end{array}$ \\
\hline 4 & Scenario 4 & $\begin{array}{l}\text { The minimum power generated by VAWT uses } 6 \text { unit of turbine blades, the } \\
\text { wind speed is } 4 \mathrm{~m} / \mathrm{s} \text {, and the power generated by VAWT is } 1.44 \text { watt. }\end{array}$ & $\begin{array}{l}\text { The base line is } 6 \text { unit of turbine } \\
\text { blades. }\end{array}$ \\
\hline 6 & Scenario 6 & $\begin{array}{l}\text { The minimum power generated by VAWT uses } 3 \text { unit of turbine blades, the } \\
\text { wind speed is } 6 \mathrm{~m} / \mathrm{s} \text {, and the power generated by VAWT is } 0.45 \text { watt. }\end{array}$ & $\begin{array}{l}\text { The base line is } 3 \text { unit of turbine } \\
\text { blades. }\end{array}$ \\
\hline
\end{tabular}

\section{Conclusions}

The $\mathrm{F}$ ratio is smaller than $\mathrm{F}$ table. It means the null hypothesis is accepted or is not different significantly at $5 \%$ from each independent variable. The scenario and the parameters during the strategy development use turbine blades, wind speed and power generated by VAWT and the maximum power generated is 16.38 watt. The wind speed is $6 \mathrm{~m} / \mathrm{s}$ and the number of turbine blade is 4 units. However, the minimum power generated by VAWT is 0.45 watt, the wind speed is $6 \mathrm{~m} / \mathrm{s}$ and the number of turbine blade is 3 units.

\section{Acknowledgment}

The authors wish to express their gratitude to the Ministry of Research, Technology and Higher-Education - Republic of Indonesia and The Director of State Polytechnics of Malang for their support.

\section{References}

[1] Creswell, JW. Research Design: Qualitative, Quantitative, and Mixed Methods Approaches.. 3rd ed. Sage Publications. New Delhi: 2009.

[2] Carrigan, TJ. Aerodyanamic Shape Optimization of A Vertical Axis Wind Turbines. Master of Science Aerospace Engineering - The University of Texas. Arlington: 2010.

[3] Dabiri, JO. Potential Order Of Magnitude Of Enhancement Of Wind Farm Power Density Via Counter-Rotating Vertical Axis Wind Turbines Arrays. Journal af Renewable and Sustainable Energy 3, 043104: 2011.

[4] DeCoste, J. Denis McKay, Brian Robinson, Shaun Whitehead, and Stephen Wright. Self Starting Vertical Axis Wind Turbine. Mechanical Engineering. Dalhousie University. 2006.
[5] Hicks, CR. Fundamental concept in the design of experiments. CBS College Publishing, New York: 1982.

[6] http://www.esdm.go.id/. Handbook of Energy and Economic Statistics of Indonesia, PUSDATIN, Jakarta (2014): Accessed on July 16, 2015.

[7] http://www.kompas.com/. Accessed on July 4, 2015

[8] http://www.ebtke.esdm.go.id/. Accessed on July 16, 2015.

[9] Kemp, WH. The Renewable Energy Handbook. Aztext Press . Canada: 2009.

[10] Kinzel, M. Quinn Mulligan and John O Dabiri. Energy Exchange in Array of Vertical Axis Wind Turbine. Journal of Turbulence. Vol. 13. No. 38. pp 1-3: 2012.

[11] Law AM and W David Kelton. Simulation Modeling and Analysis. McGraw-Hill Book Company. New York: 1982 http://www.en.wikipedia.org/wiki/simulation. Accessed on July 16, 2015.

[12] Muis, A, Priyono Sutikno, Aryadi Soewono, and Firman Hartono..Design optimization of axial hydraulic turbine for very low head application. Journal Elsevier - Energy Procedia. 2015: 68, p 262-281. https://doi.org/10.1016/j.egypro.2015.03.255.

[13] Purwono, BSA, Suyanta, and Rahbini. Bio-gas digester as an alternaive energy strategy in the marginal villages in Indonesia. Journal Elsevier - Energy Procedia. 2013: 32, p 136-144. https://doi.org/10.1016/j.egypro.2013.05.018.

[14] Purwono, BSA, Rahbini, Ubud Salim, Djuwahir, and Solimun.Analysis of dominants' factors of national renewable energy strategy. Journal Elsevier - Energy Procedia. 2015: 68, p 336-344. https://doi.org/10.1016/j.egypro.2015.03.264.

[15] Partowidagdo, W. Migas dan Energi di Indonesia: Permasalahan dan Analisis Kebijakan. Penerbit Development Studies Foundation. Bandung: 2010.

[16] Seetharam, HC, and EJ Rodgers and WH Wentz, Jr. Experiment Studies of Flow Separation of the NACA Airfoil 2412 at Low Speeds. Aeronautical Engineering Department. Wichita State University. Wichita. Kansas: 1977.

[17] Veers, PS. A General Method for Fatigue Analysis of Vertical Axis Wind Turbine. Sandia National Laboratories. Albuquerque: 1983.

[18] Wheelen, T L., and Hunger, JD. Strategic Management and Business Policy, Ninth Edition, Pearson-Prentice Hall, New Jersey: 2004. 